\title{
Levels of Serum Magnesium among Recently Diagnosed Glucose Intolerance Patients and its Comparison with Serum Magnesium Level of Sex and Age Controlled Healthy Subjects
}

\author{
KASHIF ALI SAMIN ${ }^{1}$, MUHAMMAD MUJTABA HASHIR ${ }^{2}$, SHAHEERA BATOOL ${ }^{3}$, JAZIB ANDLEEB ${ }^{4}$, NISAR KHAN SAJID ${ }^{5}$, \\ MUHAMMAD IQBAL QASIM ${ }^{6}$ \\ ${ }^{1}$ Assistant Professor Family Medicine Khyber Medical University, Peshawar \\ ${ }^{2}$ Associate Professor of Medicine, Nishtar Medical University Hospital, Multan \\ ${ }^{3}$ Assistant Professor of Biochemistry, CMH Multan Institute of Medical Science, Multan \\ ${ }^{4}$ Assistant Professor Physiology, CMH Institute of Medical Sciences, Bahawalpur \\ ${ }^{5}$ Associate Professor of Pediatric Medicine, Aziz Fatima Medical and Dental College, Faisalabad \\ ${ }^{6}$ Assistant Professor of Medicine, Frontier Medical College, Abbottabad \\ Corresponding Author: Dr. Kashif Ali Samin, E-mail: kashif@kmu.edu.pk, Phone: +923009590555
}

\begin{abstract}
Background: Hypomagnesaemia is related with diabetes mellitus (DM) and its complications and insulin resistance. On the other hand, the patients of Diabetes mellitus have decreased levels of magnesium. This analysis was planned to assess levels of serum magnesium in patients with newly diagnosedimpaired glucose intolerance and the severity of intolerance e.g., DM or impaired glucose tolerance, impaired fasting glucoseand compare the serum levels of magnesiumwith sex and age matched healthy individuals.

Methods: This case-control study was carried out in the Outpatient department of Diabetes Hospital Peshawar and $\mathrm{CMH}$ Multan Institute of Medical Science Multanfor six months duration from February 2020 to July 2020. New patients of glucose intolerance (IGT 2, DM 54) were matched with same number of sex and age matched healthy subjects $(n=56)$. All participants in the study done with the level of serum magnesium and comparisons were made between the case and the healthy subjects.

Results: This study evaluated 56 patients (studied group) and 56 healthy volunteers of similar gender and age (control group) with glucose intolerance. There was no substantial difference between the control group in terms of sex, body mass index $(p=0.39)$ and age $(p=0.88)$. The level of serum magnesium was according to standard in 30 patients and 39 healthy subjects, and decrease in 26 patients and 17 normal subjects. The mean concentration of serum magnesium was lower in the experimental group $(0.69 \pm 0.16 \mathrm{~m}$. Mol / $\mathrm{L})$ than in the control group $(0.84 \pm 0.17 \mathrm{~m}$. Mol / $\mathrm{L})$, though the variance was not substantial $(p=0.37)$.

Conclusions: The levels of Serum magnesium were lesser in individuals with IGT and DM compared to healthy volunteers of the same sex and age and levels of serum magnesium were related to blood glucose levels.

Key words: Serum magnesium, Diabetes mellitus, Glucose intolerance, Impaired glucose tolerance, Impaired fasting glucose.
\end{abstract}

\section{INTRODUCTION}

Diabetes mellitus (DM) is a universalcommunity health issue. 34.7 billion People worldwide have diabetes, which will be two-fold in the followingtwenty-years and $150 \%$ more in under developed countries ${ }^{1-2} .90 \%$ of all diabetics have type II diabetes mellitus ${ }^{3-4}$. Typically, these individuals had pre-diabetes [impaired glucose tolerance and impaired fasting glucose)]. The resistance to Insulin is the major enteropathogenic factors in the development of T2DM ${ }^{5-6}$. Low levels of magnesium (mg) have been reported in diabetic individuals, with South Asian people in particular being more at risk. Moreover, insulin resistance in more communal in hypomagnesaemia, and thus with diabetes mellitus $^{7-8}$. Hypomagnesaemia is also related with the development of complications of diabetes mellitus. Abnormal blood sugar levelscause hypomagnesaemia and osmotic diuresis, thus vicious cycle of diabetes mellitus and hypomagnesaemia initiated ${ }^{9}$. Supplements of $\mathrm{Mg}$ helps achieve good glycemic control and can avoid or delay complications. When glucose intolerant patients are tested and havedecrease levels of magnesium, replacement with $\mathrm{Mg}$ helps them attainimproved results ${ }^{10}$. This analysis was planned to assess levels of serum magnesium in patients with newly diagnosed impaired glucose intolerance and the severity of intolerance e.g DM or IGT, impaired fasting glucose and compare the serum levels of magnesium with sex and age matched healthy individuals.

\section{METHODS}

This case-control study was carried out in the Outpatient department of Diabetes Hospital Peshawar and $\mathrm{CMH}$ Multan Institute of Medical Science Multanforsix months duration from February 2020 to July 2020.New patients of glucose intolerance (IGT 2, DM 54) were matched with same number of sex and age matched healthy subjects $(n=56)$. All participants in the study done with the level of serum magnesium and comparisons were made between the case and the healthy subjects. Patients treated with type 1 diabetes, gestational diabetes (GDM) and other diabetes types, using diuretics or laxatives, having vomiting or diarrhea, detected with parathyroid disorders, malabsorption syndrome, and electrolyte imbalance were not included. The approval form the Ethical Review Commission was taken prior to study initiation. Patients had a high level of glucose intolerance according to the candidate criteria, which were collected continuously and consciously after the last Oral Glucose Tolerance Test (OGTT) in the previousthree months. Patients received 
detailed information about the purpose of the study and serum Mg level was verified after obtaining written consent. The serumMg levels have been tested by the Hospital laboratory.Other important laboratory and clinicalstatistics were obtained from patient histories as an exercise of daily routine. For healthy volunteers, the same age and gender were engaged as controls. Data were scrutinized using the SPSS version 20.0 and suitable statistical analyzes were accomplished. The outcomes are accessible in the appropriate figures and tables.

\section{RESULTS}

This study evaluated 56 patients (studied group) and 56 healthy volunteers of similar gender and age (control group) with glucose intolerance. The basic features are presented in Table I. There was no substantial difference between the control group in terms of sex, body mass index $(p=0.39)$ and age $(p=0.88)$. The level of serum magnesium was according to standard in 30 patients and 39 healthy subjects, and decrease in 26 patients and 17 normal subjects. The mean concentration of serum magnesium was lower in the experimental group $(0.69 \pm 0.16 \mathrm{~m}$. Mol / L) than in the control group $(0.84 \pm 0.17 \mathrm{~m}$. Mol / L), though the variance was not substantial ( $p=0.37$ ). The levels of serum magnesium were associated negatively with), 2-hour post glucose ( $r$ 0.560), HbA1c ( $r-0.544)$ and fasting blood glucose ( $r$ $0.532)$.
The Clinical Features of the patients are given in Table-II Serum Magnesium Level of Newly Detected Patients with Glucoselntolerance and Its Comparison with Serum Magnesium Level of Age and Sex Matched Healthy Volunteers

\begin{tabular}{|c|c|c|c|}
\hline Characteristics & Cases $(n=56)$ & $\begin{array}{l}\text { Controls } \\
(\mathrm{n}=56)\end{array}$ & $\begin{array}{l}\mathrm{p} \\
\text { value }\end{array}$ \\
\hline Age in years & $42.10 \pm 12.11$ & $3^{43.26 \pm 11.2}$ & 0.88 \\
\hline Male:Female & $1: 2$ & $1.5: 2$ & - \\
\hline BMI $\left(\mathrm{kg} / \mathrm{m}^{2}\right)$ & $26.55 \pm 2.02$ & $24.56 \pm 2.70$ & 0.39 \\
\hline $\begin{array}{l}\text { Systolic BP } \\
(\mathrm{mm} \mathrm{Hg})\end{array}$ & $131.20 \pm 15.10$ & $120.90 \pm 11.90$ & 0.002 \\
\hline $\begin{array}{l}\text { Diastolic BP } \\
(\mathrm{mm} \mathrm{Hg})\end{array}$ & $82.20 \pm 6.33$ & $1^{77.88 \pm 10.1}$ & 0.003 \\
\hline DM:IGT & 50.1 & -- & -- \\
\hline $\begin{array}{l}2-\mathrm{h} \mathrm{BG} \\
(\mathrm{m} \cdot \mathrm{mol} / \mathrm{L})\end{array}$ & $13.44 \pm 7.32$ & 一- & -- \\
\hline FBG (m.mol/L) & $9.11 \pm 1.85$ & - & - \\
\hline $\mathrm{HbA1c}(\%)$ & $7.90 \pm .85$ & - & - \\
\hline $\begin{array}{l}\mathrm{RBG} \\
(\mathrm{m} . \mathrm{mol} / \mathrm{L})\end{array}$ & 一- & $\begin{array}{ll} & 6.42 \pm 0 \\
.40 & \\
\end{array}$ & -- \\
\hline $\mathrm{Ca}(\mathrm{mg} / \mathrm{dL})$ & $8.80 \pm 0.29$ & $8.41 \pm 1.30$ & 0.003 \\
\hline $\mathrm{Mg}(\mathrm{m} . \mathrm{mol} / \mathrm{L})$ & $0.69 \pm 0.16$ & $0.84 \pm 0.17$ & 0.37 \\
\hline $\begin{array}{l}\text { S. Creatinine } \\
(\mathrm{mg} / \mathrm{dL})\end{array}$ & $0.90 \pm 0.151$ & $0.78 \pm .089$ & 0.001 \\
\hline $\mathrm{ALT}(\mathrm{U} / \mathrm{L})$ & $53.50 \pm 11.58$ & $6^{40.70 \pm 14.9}$ & 0.002 \\
\hline
\end{tabular}

The Demographic Features are given inTable-I

\begin{tabular}{|l|l|l|l|}
\hline Studied group & Control group \\
\hline Males & 19 & Males & 16 \\
\hline Females & 37 & Females & 40 \\
\hline Total & 56 & Total & 56 \\
\hline Age range & $20-40$ & 24 \\
\hline $20-40$ & 22 & $40-60$ & 32 \\
\hline $40-60$ & 34 &
\end{tabular}

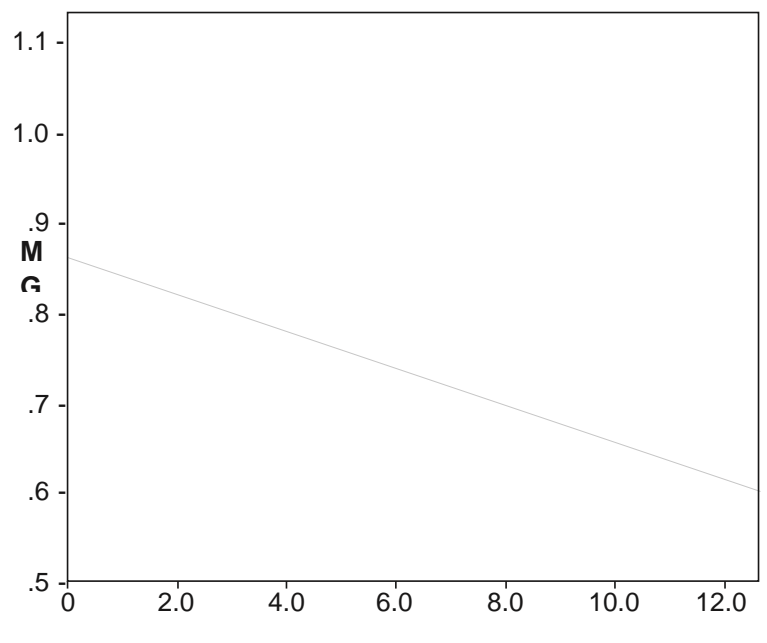

HbA1c

Figure 1.Association between serum Mg and $\mathrm{HbA} 1 \mathrm{c}$ level amid patients

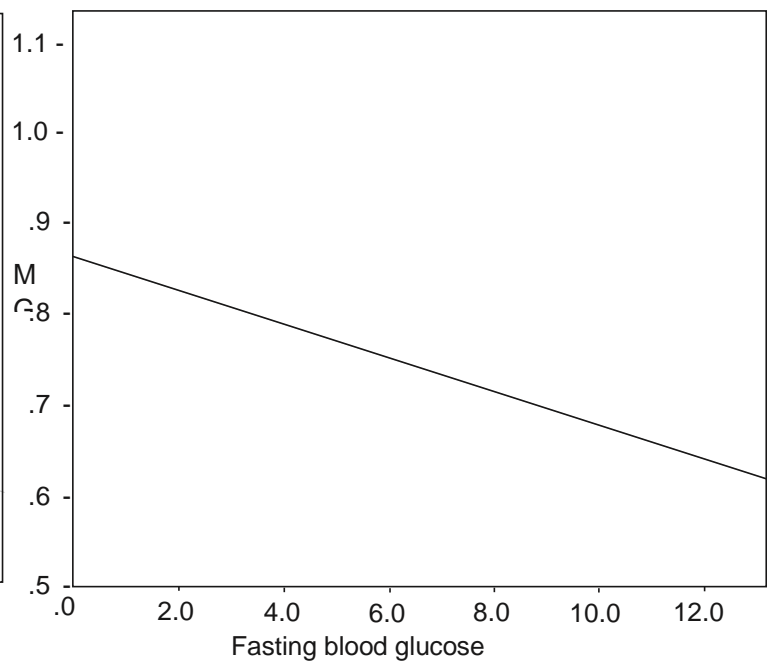

Figure 2.Association between serum Mg and FBG level amidpatients. 


\section{DISCUSSION}

$\mathrm{Mg}$ is the $2^{\text {nd }} \mathrm{utmost}$ important cell cation in the humanoid. It is an essential component of many enzymes and perform as a cofactor in above 300 enzymatic reactions ${ }^{11}$. Evidence suggests that decrease levels of $\mathrm{Mg}$ are associated with resistance of insulin and thus contribute to the progression of diabetes ${ }^{12}$. Mg supplementation can prevent the occurrence of diabetes. Among diabetic patients: Hypomagnesemia is related with neuropathy and additionalassociated complications of diabetes ${ }^{13}$. In patients of diabetes, renal $\mathrm{Mg}$ secretion is increased as a result of glucose-induced osmotic diuresis and possibly as a result of insulin resistance-induced causing reduced of tubular Mg absorption ${ }^{14-15}$. Recent studies have shown that Mg levels are low among people with recently detected glucose and $\mathrm{Mg}$ tolerance are reversed with glycemic control. Nearly all comparable results were seen in the study by Noferz et. Al in Canada ${ }^{16}$. Serum levels of $\mathrm{Mg}$ have been negatively associated with $\mathrm{HbA} 1 \mathrm{c}$ in several analysis, and the results are consistent. Improvement of hypomagnesaemia has anoptimistic effect on glycemic control, therefore dietary supplements can help diabetic patients, even if they are debatable ${ }^{17}$. Newer drugs launched for control of DM like sodium glucose transporter 2 (SGLT2) inhibitors, upsurge levels of serum $\mathrm{Mg}$ in patients of diabetes mellitus. Many of the researchesassociatedwith diabetes and serum $\mathrm{Mg}$ have been diagnosed among diabetic patients with diabetes ${ }^{18-19}$. $50 \%$ of patients with type-Il diabetes have not been diagnosed, and $1 / 3^{\text {rd }}$ to $50 \%$ of people with type II-diabetes have at least one complication at the diagnosis. Evidence has shown that correcting hypomagnesaemia helps in control of diabetes and postponed complications, while hypomagnesaemia is detected and treated early in the disease and naturally improves the patient's overall treatment outcomes ${ }^{20-21}$. The main benefit of our study was the assessment of $\mathrm{Mg}$ levels in individuals with early glucose intolerance and in this case the control regimen. However, these studies had some restrictions. This was a single-center analysis with limited quantity of study applicants. Patients with IFG were not encompassed in this study $^{22-23}$. A wider, multicenter study would provide a more meaningful response with more study participants.

\section{CONCLUSION}

Although there was no significant variance in serum $\mathrm{Mg}$ levels between recentlyperceived glucose intolerancewith serum $\mathrm{Mg}$ levels of sex and age matched healthy volunteers in this analysis, serum Mg levels were found decreased in glucose intolerance patients (IGT and DM). Among glucose intolerance patients, serum $\mathrm{Mg}$ concentration was negatively associated with glycemic control.

\section{REFERENCES}

1. Zangana SN, Khazaal SA. Evaluation of Serum Magnesium Level Among Patients with Essential Hypertension in ErbilIraq. Diyala Journal of Medicine. 2021 Jun 25;20(2):23-30.

2. Thadani D, Jawa K, Mahawar S, Makwana A. EVALUATION OF SERUM MAGNESIUM LEVEL IN PREDIABETIC
SUBJECTS IN INDIAN POPULATION. Indian Journal of Scientific Research. 2021 Jan 1;11(2):53-8.

3. Oost LJ, van der Heijden AA, Vermeulen EA, Bos C, Elders PJ, Slieker RC, Kurstjens S, van Berkel M, Hoenderop JG, Tack CJ, Beulens JW. Serum Magnesium Is Inversely Associated With Heart Failure, Atrial Fibrillation, and Microvascular Complications in Type 2 Diabetes. Diabetes Care. 2021 Jun 16.

4. Fadel MM, Ghaffar FR, Zwain SK, Ibrahim HM. Serum netrin and VCAM-1 as biomarker for Egyptian patients with type II diabetes mellitus. Biochemistry and Biophysics Reports. 2021 Sep 1;27:101045.

5. Rao NS, Raju GN, Tiwari MK, Naidu BG, Sarita P. Serum Elemental Analysis of Type 2 Diabetes Patients Using SRXRF. Biological Trace Element Research. 2021 Jun 2:10.

6. Flockhart M, Nilsson LC, Tais S, Ekblom B, Apró W, Larsen FJ. Excessive exercise training causes mitochondrial functional impairment and decreases glucose tolerance in healthy volunteers. Cell metabolism. 2021 May 4;33(5):95770.

7. Babapour M, Mohammadi H, Kazemi M, Hadi A, Rezazadegan M, Askari G. Associations between serum magnesium concentrations and polycystic ovary syndrome status: a systematic review and meta-analysis. Biological Trace Element Research. 2021 Apr;199(4):1297-305.

8. Pancholi V, Smina TP, Kunnumakkara AB, Maliakel B, Krishnakumar IM. Safety assessment of a highly bioavailable Curcumin-galactomannoside complex (CurQfen) in healthy volunteers, with a special reference to the recent hepatotoxic reports of curcumin supplements: A 90-days prospective study. Toxicology Reports. 2021 Jun 16.

9. Bielach-Bazyluk A, Zbroch E, Czajkowska K, Koc-Zorawska E, Kakareko K, Rydzewska-Rosolowska A, Hryszko T. Serum sirtuin 1 is independently associated with intact PTH among patients with chronic kidney disease. Clinical Interventions in Aging. 2021;16:525.

10. Montefusco L, Nasr MB, D'Addio F, Loretelli C, Rossi A, Pastore I, Daniele G, Abdelsalam A, Maestroni A, Dell'Acqua $M$, Ippolito E. Acute and long-term disruption of glycometabolic control after SARS-CoV-2 infection. Nature Metabolism. 2021 May 25:1-2.

11. Abdelkader RY, Abdelrazek MA, Attallah A, Farid K, El-Far M. High blood glucose levels are associated with fibrosis/cirrhosis progression in chronic hepatitis C. Journal of Immunoassay and Immunochemistry. 2021 Apr 23:1-2.

12. Mostafa TM, El-Gharbawy NM, Werida RH. Circulating IRAPe, Irisin, and IL-34 in Relation to Insulin Resistance in Patients With Type 2 Diabetes. Clinical Therapeutics. 2021 Jun 5.

13. Roy A, Kamalanathan S, Sahoo J, Kar SS, Naik D, Narayanan N, Merugu C, Patel D. Comparison of islet cell function, insulin sensitivity, and incretin axis between AsianIndians with either impaired fasting glucose or impaired glucose tolerance, and normal healthy controls. Diabetes Research and Clinical Practice. 2021 Jun 1;176:108846.

14. Pepe J, Colangelo L, Sonato C, Occhiuto M, Ferrara C, Del Fattore A, Santori R, Mastrantonio M, Sgreccia A, Minisola $\mathrm{S}$, Cipriani C. Echocardiographic findings in patients with normocalcemic primary hyperparathyroidism compared with findings in hypercalcemic primary hyperparathyroid patients and control subjects. Endocrine Practice. 2021 Jan $1 ; 27(1): 21-6$.

15. Lashari A, Afridi HI, Kazi TG, Talpur FN, Baig JA, Chanihoon $\mathrm{GQ}$, Channa GM. Interaction between Cadmium and Zinc Levels in the Biological Samples of Type 1 Diabetic Mellitus Children, Reside in Different Areas of Sindh, Pakistan. American Journal of Analytical Chemistry. 2021 Jun 10;12(6):241-59. 
16. Chang JS, Namkung J. Effects of Exercise Intervention on Mitochondrial Stress Biomarkers in Metabolic Syndrome Patients: A Randomized Controlled Trial. International journal of environmental research and public health. 2021 Jan;18(5):2242.

17. Damen L, Donze SH, Grootjen LN, Hokken-Koelega AC. Long-term cortisol levels in hair of children and adolescents with Prader-Willi Syndrome. Psychoneuroendocrinology. 2021 Jun 20:105335.

18. Yildirim A, Sumbul HE, Koca H, Kucukosmanoglu M, Icen YK, Koc M. Complement C1q/Tumor Necrosis FactorRelated Protein-3 (CTRP3) is Significantly Decreased in Patients with Heart Failure and Closely Related with Ventricular Tachycardia. Acta CardiologicaSinica. 2021 May;37(3):278.

19. Yadav N, Chandra S, Singh K, Yadav A, Sharma A. Assessment of Prognostic markers of Diabetic NephropathySerum Creatinine and Blood Urea Levels in Diabetes mellitus and healthy individuals at tertiary care hospital.
European Journal of Molecular \& Clinical Medicine (EJMCM).;7(11):2020.

20. Duan $Y$, Sun H, Yao Y, Han L, Chen L. Perturbation of serum metabolome in relation to type 2 diabetes mellitus and urinary levels of phthalate metabolites and bisphenols. Environment International. 2021 Oct 1;155:106609.

21. Hossain MF, Haq T, Fariduddin M, Selim S, Hasanat MA, Shahed-Morshed M. Vitamin D and Its Association with Glycemic Status in Bangladeshi Adults with Newly Detected Type 2 Diabetes Mellitus. Open Journal of Endocrine and Metabolic Diseases. 2021 Jan 18;11(1):1-1.

22. Takaya J, Tanabe Y, Kaneko K. Increased lipocalin 2 levels in adolescents with type 2 diabetes mellitus. Journal of Pediatric Endocrinology and Metabolism. 2021 Jun 14.

23. Lee SB, Kwon HC, Kang MI, Park YB, Park JY, Lee SW. Increased prevalence rate of metabolic syndrome is an independent predictor of cardiovascular disease in patients with antineutrophil cytoplasmic antibody-associated vasculitis. Rheumatology International. 2021 Jun 4:1-2. 